UHERO

THE ECONOMIC RESEARCH ORGANIZATION AT THE UNIVERSITY OF HAWAI'I

\section{TECHNICAL PROGRESS IN TRANSPORT AND THE TOURISM AREA LIFE CYCLE}

BY

ANDREW KATO AND JAMES MAK

Working Paper No. 2010-13

September 28, 2010 


\title{
Technical Progress in Transport and the Tourism Area Life Cycle
}

\author{
Andrew Kato \\ University of Hawaii Economic Research Organization \\ University of Hawaii at Manoa \\ 2424 Maile Way, Saunders Hall \\ Honolulu, Hawaii, U.S.A. 96822 \\ E-mail: akato3@hawaii.edu \\ James Mak \\ Department of Economics and University of Hawaii Economic Research Organization \\ University of Hawaii at Manoa \\ 2424 Maile Way, Saunders Hall \\ Honolulu, Hawaii, U.S.A. 96822 \\ E-mail: jmak@hawaii.edu
}

\begin{abstract}
Richard Butler's tourism area life cycle envisions tourism destinations to evolve in stages from exploration to rapid growth followed by slackening, stagnation, and even decline. The eventual slow-down in tourism growth is attributed to the destinations reaching their physical and social carrying capacities. This article examines the evolution of Hawaii as a tourism destination from 1922 to 2009. We demonstrate that tourism growth in Hawaii has declined but not because the destination has reached its carrying capacity but primarily because of the slowdown in technical progress in passenger air transportation and competition from newer destinations. We conclude that for destinations that depend on transportation improvements to attract tourists, technical progress in transport may provide a better explanation of the evolution of their destinations than their carrying capacities.
\end{abstract}

Key words: Tourism Area Life Cycle, Transportation, Technical Progress

Draft: Not to be cited or reproduced without permission. 


\subsection{Introduction}

In 1980, Richard W. Butler published his now classic article in the Canadian Geographer in which he adapted the concept of the product life cycle from the marketing literature to describe the evolution of tourism destinations (Butler, 1980; also in Butler, 2006, pp. 4-9). As with new products, Butler posited that destinations typically go through several stages from commencement to rapid growth and maturity and ultimately to possible decline when the destination's carrying capacity is exceeded by the arrival of too many tourists. Butler wrote (Butler, 2006, pp. 4-9):

The pattern which is put forward here is based upon the product cycle concept, whereby sales of a product proceed slowly at first, experience a rapid rate of growth, stabilize, and subsequently decline; in other words, a basic asymptotic curve is followed.

Visitors will come to an area in small numbers initially restricted by lack of access, facilities, and local knowledge. As facilities are provided and awareness grows, visitor numbers will increase. With marketing, information dissemination, and further facility provision, the area's popularity will grow rapidly. Eventually, however, the rate of increase in visitor numbers will decline as levels of carrying capacity are reached. These may be identified in terms of environmental factors (e.g. transportation, accommodation, other services), or of social factors (e.g. crowding, resentment by the local population). As the attractiveness of the area declines relative to other areas, because of overuse and the impacts of visitors, the actual number of visitors may also eventually decline. The stages through which it is suggested that tourist areas pass are illustrated in Figure 11.1... 
Figure 11.1

Butler's Hypothetical Tourism Area Life Cycle

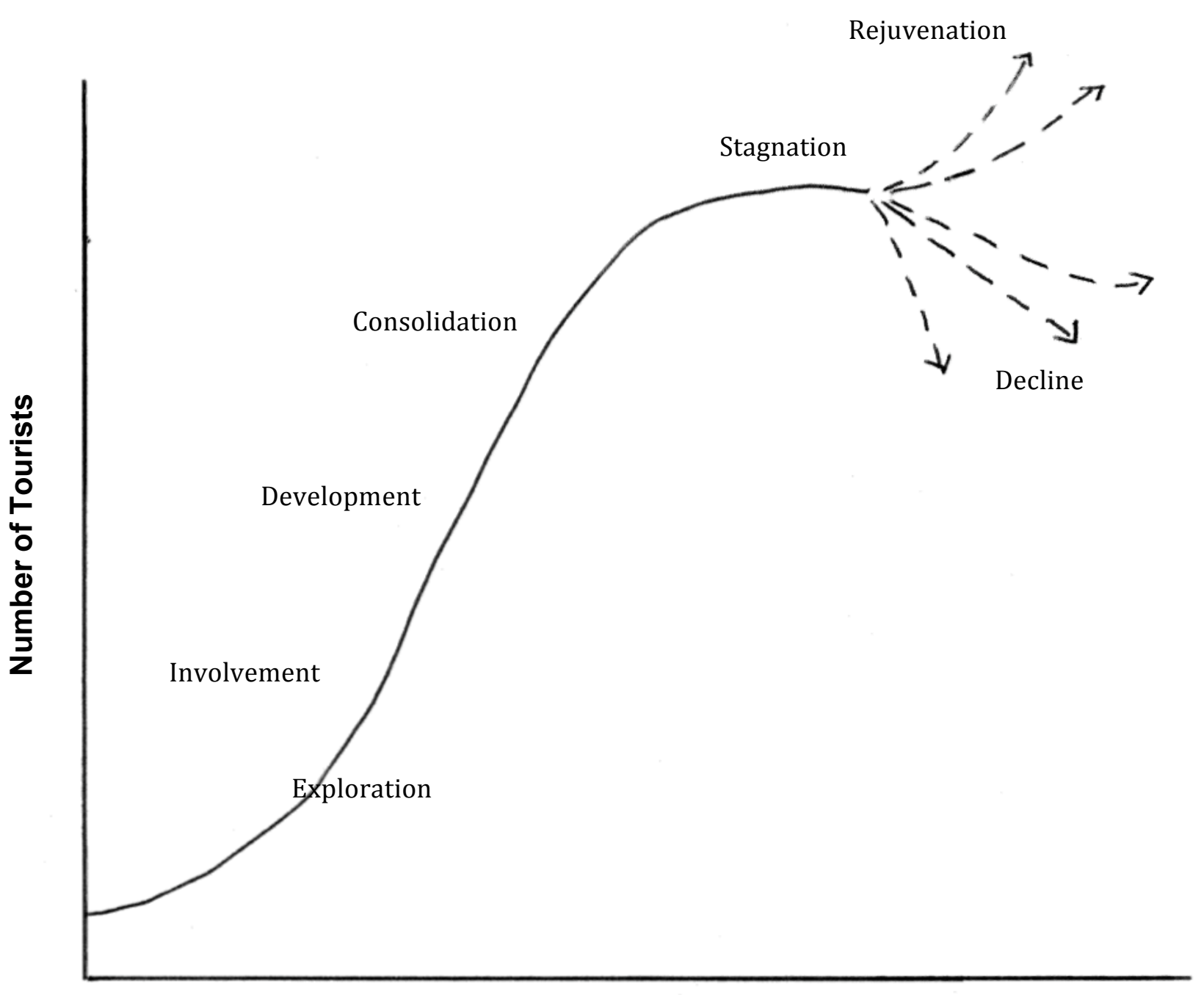

Time

Source: Butler (1980).

Butler's article has spawned an entire industry devoted to the interpretation, critique, and suggestions for improvement to the TALC. The publication of two volumes of essays on the subject in 2006 by prominent tourism scholars, and edited by Butler (2006 and 2006a), provide a rich sample of the 
vast literature on the TALC. ${ }^{1}$ To date studies on the TALC largely have been authored by geographers. Very few empirical studies have appeared primarily because lengthy data series on tourist arrivals for individual destinations are scarce.

11.2 Economics Literature on the Life Cycle of Industries and Implications for Tourism Destinations

Economic historians have been conducting empirical analyses of industry life cycles from at least the 1930s, among the most notable include Nobel laureate Simon S. Kuznets who published his Secular Movements in Production and Prices in 1930. Kuznets wrote (1930, p. 1):

As we observe the various industries within a given national system, we see that the lead in development shifts from one branch to another.

The main reason for this shift seems to be that a rapidly developing industry does not continue its vigorous growth indefinitely, but slackens its pace after a time, and is overtaken by industries whose period of rapid development comes later. Within any country we observe a succession of different branches of activity leading the process of development, and in each mature industry we notice a conspicuous slackening in the rate of increase.

Kuznets fitted curves to output data for manufacturing and extractive industries from five industrial countries and found that industries tended to experience slower rates of growth over time. ${ }^{2} \mathrm{He}$ attributed the retardation of an industry to several factors: (1) the slackening of technical progress, (2) retardation of (other) industries which supply it with raw materials or complementary goods, (3) decrease in available funds for further expansion, and (4) competition from the same industry in a younger country (Kuznets, 1930, pp. 41-53). He explained that all four factors are related to technical change and its eventual slackening.

Four years later in 1934, Arthur F. Burns published his parallel work, Production Trends in the United States Since 1870. Burns reached the same conclusion as Kuznets. Like Butler, Burns (1934, pp. 172-173) suggested that the life cycle of industries can also be divided into "stages", the nascent stage, the maturity stage, and the decadence stage and that they differ in duration and intensity from industry to industry. He analyzed statistically the outputs of 142 industries in the U.S since 1870 and found (p. 118) that "Retardation has taken place in a preponderant number of the industries covered in our survey." His study also included a few declining industries. He found (pp. 160-162) "decadent industries" tend to show

${ }^{1}$ A count of the articles published between 1980 and 2003 and cited in these essays that contained either "the tourist area life cycle" or "destination life cycle" in their titles totaled nearly 70. A literature review by Richard Lagiewski (Butler, 2006, Chapter 3) of the "major works" on the subject contained over 50 articles.

2 Kuznets (1930, pp. 324-325) found the simple logistic curve to provide the best description of the longrun trend. 
slower rates of decline after some period of decline rather than accelerate into extinction. He then surmised (p. 162) that "a structural change" might take place in a declining industry "which once rejuvenated--would embark on a new career of rapid growth and retardation."

More recent economic studies on the industry life cycle (e.g. Klepper, 1996; Jovanovic and MacDonald, 1994; Klepper and Graddy, 1990; Gort and Klepper, 1982) take an industrial organization approach and focus on firm entry and exit and the total number of firms over the life cycle of an industry. Their findings also support the earlier work by Kuznets and Burns. The typical life cycle of an industry is described as follows: A young industry begins with only a few firms producing many different versions of the industry's product. The new firms were initially established to take advantage of a product innovation. With few competitors, high prices prevail and profits rise, inducing entry of new firms. The increase in the number of firms results in dramatically higher total output and lower prices. Rising output and declining prices also stem from falling costs of production attributable to both improvements in production processes and economies of scale. Output continues to grow but the annual rate of growth of output, as well as the rate of decline in prices, eventually slacken inducing some firms to leave the industry. However, it is not uncommon for an industry to depart from the general pattern of a fall in the percentage rate of growth in its output and the percentage rate of decline in its prices at some time during its history. In the long run, only firms with sufficiently low cost and/or high product qualities survive.

Technical progress is seen by economists to play a crucial role in the life cycle of industries as it can affect both the demand for and supply of commodities. Innovation that leads to the development of a new product creates new demand, and improvement to an existing product increases the demand for it. On the supply side, technical progress that reduces production costs leads to lower product prices resulting in greater quantity demanded. As technical progress slows, so does the growth of the industry.

Assuming that tourism destinations can be viewed as industries, these studies suggest the following stylized profile of evolution for tourism destinations. First, over the course of a destination's life, it can experience more than one cycle of growth and retardation. Second, each cycle has an approximate beginning initiated by a major technical break-through or "structural change", a period of rapid growth followed by slower growth, maturation, stagnation, and either decline or rejuvenation. Third, growth may not be strictly monotonic as there could be periods when the rate of growth of tourism can depart from a smooth curve. Fourth, if decline does finally come, it could be an extended one rather than acceleration into extinction as efforts are made to slow its progression. Fifth, if another major technical change or "structural change" comes along, it can initiate a new cycle of growth, retardation, stagnation and so on. Sixth, extinction is not inevitable.

Economists and Butler differ on the principle factor behind the secular retardation of industries/tourism destinations. For example, Kuznets focused on the slow down in technical progress as 
the most important factor in explaining the retardation of industries over time. By contrast, Butler focused on the destination's carrying capacity. ${ }^{3}$ Both were aware that the factor that each had singled out does not represent a complete list of factors that explain the growth of an industry/tourism destination (Kuznets, 1930, p. 53; Butler, 1998; Butler, 2006a, p. 282). Kuznets (p. 53) emphasized technical change because it "seemed to us to be paramount."

Hawaii provides an excellent illustration of the relative importance of technical progress versus carrying capacity in explaining the evolution of this premier tourist destination. For Hawaii, the technical progress of significance is in passenger transportation, notably in aviation. Hawaii has reliable annual data on visitor arrivals since at least 1922 (Table 11.1A, Appendix). ${ }^{4}$ The existence of a continuous series of tourism data for a single destination for over 80 years is rare. Moreover, Hawaii's tourism product, while changed over the years, has not changed drastically since the turn of the $20^{\text {th }}$ century. Tourists have always been attracted to Hawaii by its exceptional natural amenities--the sun, sand, and sea. A uniform market has often been cited as one of the requirements for the TALC to apply (Lundtorp and Wanhill in Butler, 2006a, p. 149). For destinations such as Hawaii that rely on the development and diffusion of transport technology to attract tourists, Kuznets' technical change based theory may provide a superior explanation of their life cycles than Butler's carrying capacity theory.

\subsection{The Life Cycle of Hawaii's Tourism Industry/Destination}

Tourism grew at a modest pace in Hawaii between 1922 and 1941, interrupted by four straight years of decline during the Great Depression of the 1930s. However, the numbers were still small. On the eve of America's entry into World War II in 1941 the number of visitor arrivals in Hawaii totaled only about 26,000. Rapid growth came after World War II after the tourism business resumed operation following its suspension (1942-1945) during the War when transportation and hotel facilities were transferred to military use. Between 1946 and 2009, the evolution of Hawaii as a tourist destination

3 There are several definitions of a destination's "carrying capacity" (see Martin and Uysal, 1990, pp. 328-330.) Butler's (1980) definition is rather curious. His notion of physical carrying capacity includes "transportation, accommodation, and other services" which are reproducible services. Since the TALC is a long run model of tourism destination evolution, the critical physical capacity constraints are those which are non-reproducible, technology cannot surmount, and good substitutes cannot be found in the long run. Environmental resources come to mind (Tisdell, 2005, Chapter 10). The World Tourism Organization (UNWTO) defines carrying capacity as "the level of visitor use an area can accommodate with high levels of satisfaction for visitors and few impacts on resources." (Mak, 2004, p 176). The social carrying capacity notion can be added to the UNWTO definition by adding the words "and residents" after "high levels of satisfaction for visitors" to complete the definition. This is the notion of "carrying capacity" employed here.

${ }^{4}$ Crampon (1976, Appendix, Table III, pp. 316-317) estimated the number of visitor arrivals in Hawaii back to 1800 . Nineteenth century visitor arrivals in Hawaii comprised mostly of visiting merchant seamen and whalers. The rise and decline of whaling in the North Pacific during the $19^{\text {th }}$ century provided Hawaii its first tourism cycle. 
followed in near picture-perfect fashion Butler's TALC, with rapid growth in the late 1940s through the 1960s, slower growth thereafter until 1990, and maturity and stagnation after that (Figure 11.2). If we consider the years before 1942 as the commencement of modern tourism in Hawaii, we can focus most of our attention on the explanation of its stunning growth after 1945.

Figure 11.2

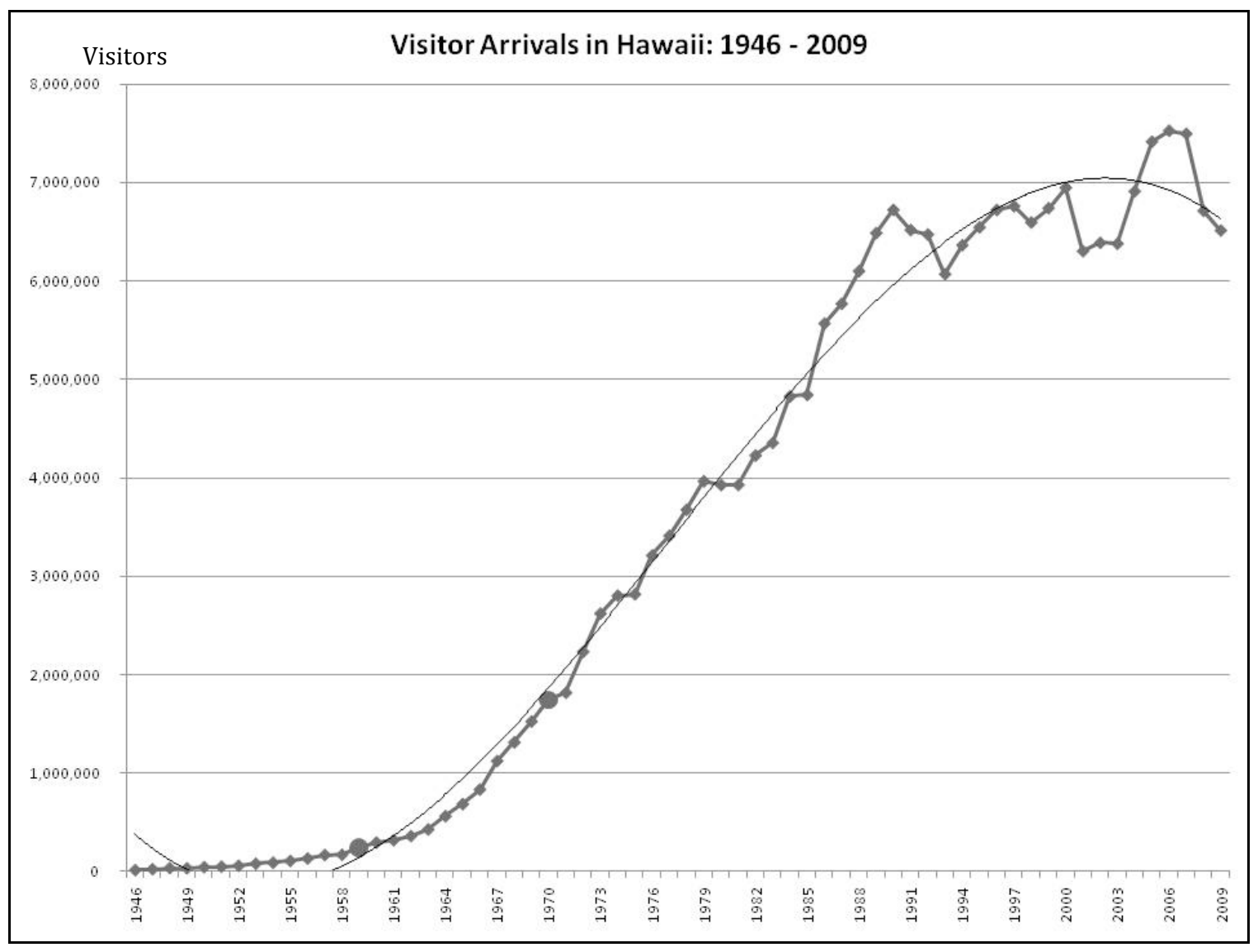

Source: Table 11.1A, Appendix.

\subsubsection{The Beginning: The Nascent Period}

Crampon (1977) noted that Hawaii had a tourist trade going back to the early $19^{\text {th }}$ century. But it was not until after 1870 that one could say Hawaii really became a tourist destination when regular steamship service between the U.S. west coast and Hawaii was firmly established. Cargo and passengers were carried on the same ship then, but it was cargo that was more valuable. In 1903 Hawaii established its first tourism bureau. The Roaring Twenties saw sizable increases in the number of visitors to the islands. America's economy was booming, population on the west coast was increasing rapidly, and ships were faster and sailed more frequently. In 1927, the first of what would be Matson Navigation Company's 
fleet of "White Ships" -the 20,000 ton, 650-passenger Malolo--made its maiden voyage to Hawaii carrying 419 (all first class) passengers; it was the largest and fastest passenger ship in the Pacific cruising at a fleet 21 knots. The Malolo joined a fleet of 8 other Matson ships offering 7 trips to Hawaii from San Francisco and Seattle every month at an advertised price of “\$270, up” for “all expense tours” (O’Brien, 2008, p. 30). Matson would build three more luxury passenger liners in the early 1930s (O'Brien, 2008). In addition to bringing most of the tourists to Hawaii, Matson owned and operated two of the finest hotels in Waikiki, the Moana and the Royal Hawaiian. Indeed, when the Royal Hawaiian Hotel was opened in 1927, it was considered one of the finest hotels in the world (Cohen, 2001). ${ }^{5}$ Matson's name became synonymous with Hawaii tourism (Allen, 2004, p. 4).

On October 21, 1936 Pan American Airlines introduced its Clipper service from San Francisco to Manila via Honolulu, using the long-range flying boat, the Martin M-130. ${ }^{6}$ The M-130 could carry 32 passengers and cruise at a speed of 130 miles per hour. On its inaugural flight, the Hawaii Clipper from San Francisco to Honolulu carried 7 passengers at a one-way (first class only) fare of \$356 (Crampon, 1976, p. 233). While flying by air was much more expensive than by steamer, speed-wise, it was a big improvement over a 5-day ship voyage on the fastest steamer; the M-130 flying boat took about 20 hours to reach Hawaii. For the next few years, Pan Am, which held a monopoly on the route, flew a once-a-week schedule between San Francisco and Manila, with stopovers in Honolulu, Midway Island, Wake Island, and Guam (stops were necessary for refueling).

Not long after the M-130 was put into service, Pan Am introduced the improved B-314 flying boat which provided somewhat longer range and slightly more air speed but a much larger passenger load, 70 passengers instead of $32 .^{7}$ The scheduled flying time was cut to 17 hours and 30 minutes at a nominal one-way fare of $\$ 278$.

The flying boats did not bring a dramatic change in tourist travel to Hawaii. High fares and limited capacity explain why almost all (98.9 percent) the arriving passengers in Hawaii before World War II came to Hawaii by ship (Crampon, 1976, p. 284). The persistence of ship travel is not surprising as it is not uncommon to see a new innovation not displace an old technology right away. As noted by Kuznets,

5 Two other hotels, the Surfrider and the Princess Kaiulani were built after the War (Allen, 2004, p. 4). By owning hotels, Matson was able to sell transportation and accommodation packages that no other transportation company could at the time.

${ }^{6}$ Actually the first scheduled flight by the China Clipper was in November, 1935 taking 21 hours; but that flight carried only mail. Only 3 of the Clippers were built, the China Clipper, the Philippine Clipper and the Hawaii Clipper. See http://www.aviation-history.com/martin/m130.html. [accessed 7 September 2010]

${ }^{7}$ See http://www.clipperflyingboats.com/pan-am/boeing-b314. The B-314, also dubbed a "Clipper" ship by Pan Am, could carry 74 passengers (40 passengers in sleeper configuration); had a 14-seat dining room, and even a private honeymoon suite at the back of the plane. At a standard cruising speed of 183 miles per hour, it was not a much faster plane than the M-130. [accessed 7 September 2010] 
new innovations are rarely perfect at the beginning, thus allowing old technologies to persist for quite some time. ${ }^{8}$ On the eve of America's entry into WWII in 1941, over 62,000 trans-Pacific passengers arrived in Hawaii by ship; by comparison no more than a thousand came by air (Schmitt, 1977, p. 452 and 460; Crampon, 1976, p. 284). ${ }^{9}$

\subsubsection{End of WWII to 1990: The Sustained Growth Stage}

World War II put Hawaii's tourism industry out of business from 1942 to 1945 . Following WWII, it took a few years before tourism in Hawaii finally surpassed the level attained before the War. In 1949, there were 34,000 visitor arrivals in Hawaii. By Statehood in 1959, the number had increased to 243,000 . During the '50s the annual growth rate of visitor arrivals averaged nearly 21 percent. In no decade since then has Hawaii experienced a higher (average) rate of growth. The annual growth rate during the ' 60 s averaged 19.7 percent, 8.7 percent in the ' 70 s, and 5.6 percent in the ' 80 s (Table 11.3). While the rate of growth slackened over time, the spectacular increase in visitor numbers was what caught people's attention and, beginning in the mid-1970s, fueled resident demand for government intervention to curb tourism's growth (Mak, 2008, Chapter 3). By 1990, visitor arrivals reached 6.7 million, or nearly 28 times that in 1959.

Long time Hawaii tourism executive, Robert Allen, opined that three elements were primarily responsible for Hawaii's phenomenal post-WWII growth in tourism: the jet airliners, the mega-resorts, and the travel agents (Allen, 2004, p. 22). Technical progress in air transportation was clearly the most important; the other two were dependent on the former. More speed, lower cost, and greater passenger carrying capacity offered by newer and more technically advanced airplanes were instrumental in the accelerated development of Hawaii tourism after WWII. But it was not the jet plane alone that propelled the take-off.

Even before the introduction of jet plane service to Hawaii in 1959, one cannot readily dismiss the contribution of land-based piston engine planes to the expansion of tourism in the isles. After WWII, Pan American's flying boats were replaced by land based planes which could fly faster, carry more passengers, and operated at lower cost: the DC-4 in 1946, and shortly thereafter the luxurious Boeing 377 Stratocruiser, ${ }^{10}$ various editions of the Lockheed Constellation ${ }^{11}$ and the DC- 6 in the early $1950 \mathrm{~s},{ }^{12}$ and

\footnotetext{
${ }^{8}$ See, also, Rosenberg (1972). Indeed, air and ocean transportation provided complementary services. In June 1935, Pan Am and Matson signed an agreement whereby Pan Am would furnish meteorological services to Matson and Matson agreed to ship passenger baggage for the airline (Davies, 1972, pp. 250251).

${ }_{9}^{9}$ There were less than 1,200 arriving, departing, and through air passengers; no separate passenger counts were reported for each category.

10 Pan Am introduced the Boeing 377 Stratocruiser to Hawaii service in 1949. The plane, adapted from the WWII B-29 bomber, was the first truly intercontinental airliner with a range of 4,600 miles and a cruising speed of $300 \mathrm{mph}$ carrying up to 100 passengers and crew. It had an extra wide passenger cabin
} 
finally the fastest of the piston engine planes, the DC-7 in the mid-1950s. ${ }^{13}$ With the average aircraft speed increasing from 200 to over 300 miles per hour in a matter of a couple of years after the introduction of the DC-4, flight time from San Francisco to Hawaii was cut from 17 hours and 30 minutes in the B-314 flying boat, to 11 hours 45 minutes in a DC-4, to 9 hours and 25 minutes in a Boeing 377 Stratocruiser, and finally to 8 hours and 25 minutes in a DC-7. The one-way first class airfare between San Francisco and Honolulu fell from $\$ 278$ on the B-314 to $\$ 178$ (excluding taxes) in nominal dollars; but the introduction of an economy fare brought the lowest one-way passenger fare down to $\$ 125$ by 1952 . The initial first class one-way fare of $\$ 195$ on the DC-4 in 1946 was 35 percent less expensive than a ticket on the B-314, and it quickly fell to around $\$ 160$ three years later. Thus, technical progress in air transportation brought down prices and the time cost of travel. It also brought improved service; for example, cabin pressurization was not introduced until the DC-6. The rate of growth of tourism accelerated in tandem with technical advancements in airplanes after 1946 (See Figure 11.3). Nonetheless, while tourism grew at an impressive pace in the 1950s, the count of visitor arrivals was still modest.

and a lower level beverage lounge. See http://www.boeing.com/history/boeing/m377.html [accessed 7 September 2010].

11 These included the L049, L749, L1049 and finally the L1649 Starliner. Each of these planes could cruise at speeds in excess of 300 miles per hour; the maximum passenger loads increased from 54 passengers for the L049 to nearly 100 for the L1649. The "Connie", judged a commercial failure, was not as economically efficient a plane to fly as the Douglas (DC) family of planes. See http://www.historynet.com/the-legendary-lockheed-constellation.htm [accessed 7 September 2010]. 12 The DC6 Cloudmaster had a cruising speed of about 300 miles per hour with a standard passenger load of between 45 to 56. See http://www.airliners.net/aircraft-data/stats.main?id=190 [accessed 7 September 2010].

13 The DC-7s could carry about 100 passengers at a cruising speed of about 350 miles per hour. See http://www.airliners.net/aircraft-data/stats.main?id=191 By comparison, the DC-4 could carry a standard passenger load of only 44 passengers and fly at a cruising speed of about 210 miles per hour. See http://www.airliners.net/aircraft-data/stats.main?id=189 [accessed 7 September 2010]. 
Figure 11.3

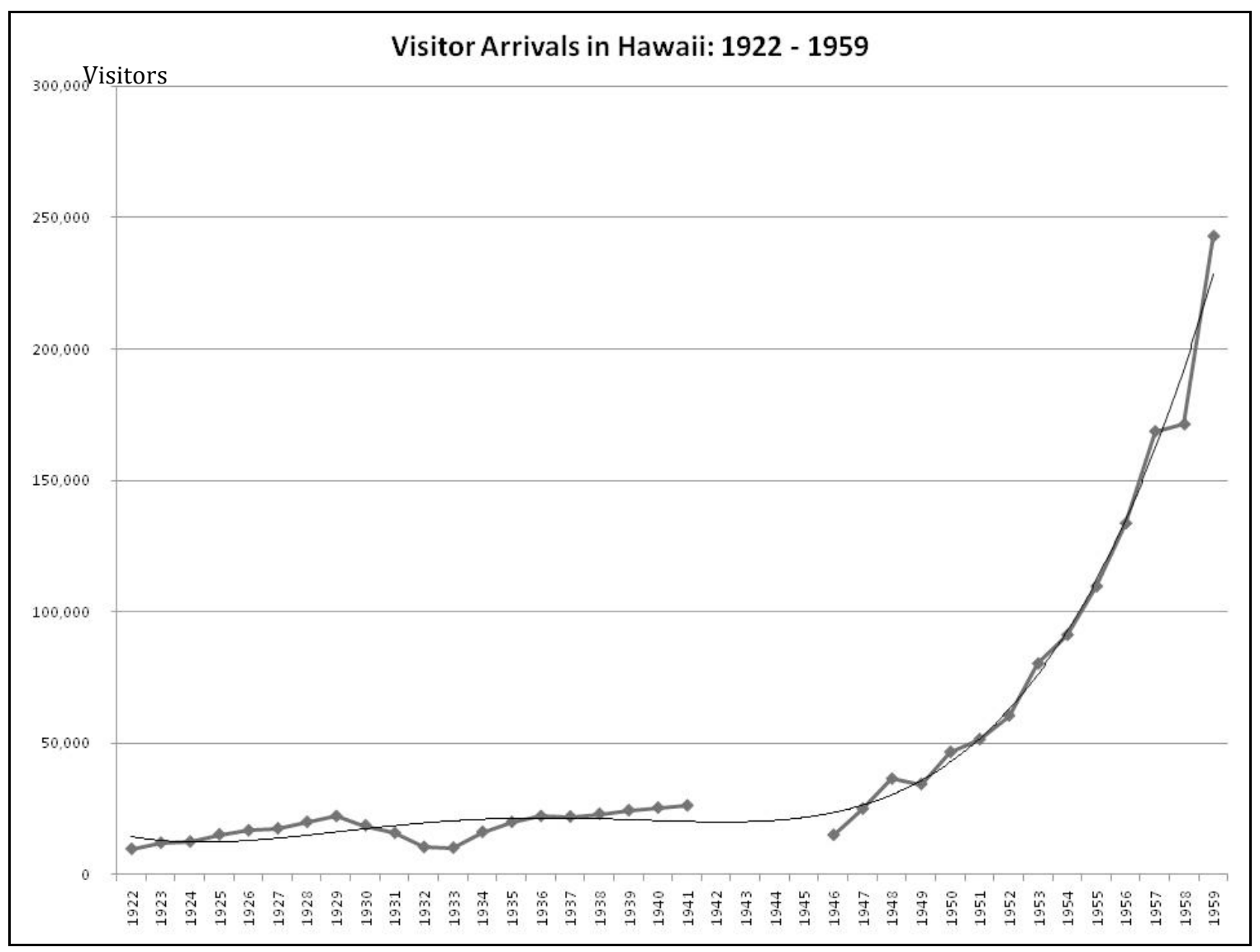

Source: Table 11.1A, Appendix.

Nineteen fifty-nine (1959) was an auspicious year for Hawaii. Hawaii became America's $50^{\text {th }}$ state, and the occasion produced a spike ( +41.8 percent) in tourist arrivals in that year. However, another event would ultimately be more important to the long-run growth of tourism in Hawaii. In 1959 Pan Am inaugurated jet plane service to Hawaii using the Boeing 707 that could carry around 180 passengers. The Boeing 707 was able to carry almost twice as many passengers as a DC-7 and cut travel time by another 3 hours to 5 hours. ${ }^{14} \mathrm{~A}$ faster plane could make more round trips in a given amount of time thus making the crew and plane more productive; the average cost of operating a craft on a given flight fell (Goodman, 2000, p. 41). So did airfares. Between 1960 and 1970, the price of a one-way coach ticket between San Francisco and Honolulu - adjusted for inflation - fell by nearly fifty percent (Mak, 2008, p. 16). By the mid-1960s, the era of the piston engine plane had come to an end.

14 Jet service was also more reliable (Allen, 2004, p. 22). 
Then in 1970, the Boeing 747 jumbo jet came into Hawaii service. ${ }^{15}$ While it did not fly any faster than the Boeing 707, it could carry nearly three-times as many passengers depending on the configuration, enabling airlines to carry large groups of people who wished to travel together (i.e. the group package tour). ${ }^{16}$ The Boeing 747 was also more luxurious. Because it could carry more passengers than the largest piston engine planes, the Boeing 747 and other jumbo jets (i.e. the McDonnell Douglas' DC-10 and the Lockheed 1011) were even less costly to operate.

Cost savings from using faster and bigger planes in the 1960s and 1970s were passed on to consumers via lower airfares. Lower time and money cost of travel led to a reduction in the average length of stay in Hawaii as more people found it worthwhile to take shorter but more frequent trips to Hawaii. The change in consumer behavior confirms Gronau's (1970) hypothesis regarding the relationship between travel cost, trip duration, and repeat visitation: The lower the cost of travel, the greater is the passenger's tendency to stay shorter at the destination and to increase the frequency of trips. ${ }^{17}$ Thus, technical progress in air transportation not only increased the number of people able and willing to travel, it also changed their travel behavior once they arrived at their destination. ${ }^{18}$

Along with technical progress in aviation, there were also significant organizational changes in air service that stimulated tourist travel to Hawaii. Until 1947, Pan Am enjoyed a monopoly in providing air passenger service between the West Coast and Hawaii through its sole gateway in San Francisco. Until airline deregulation was enacted in the U.S. in 1978, the Civil Aeronautics Board (CAB) tightly controlled airfares and airline entry and exit in interstate air passenger transportation (Biederman, 1982) ${ }^{19}$ In 1947, after many years of deliberation, the CAB permitted two more American carriers to fly to Hawaii: United Airlines in 1947 to serve San Francisco and in 1950 to also serve Los Angeles, and Northwest Orient in 1948 to serve Seattle and Portland. Though a relative newcomer, United Airlines would become the largest

15 The first of the Boeing 747s denoted as Boeing 747-100 could cruise at a speed of 555 miles per hour carrying 366 passengers in a 3-class configuration or 452 passengers in a 2-class configuration. See http://www.boeing.com/commercial/747family/pf/pf classics.html [accessed 7 September 2010].

16 Fares, which were regulated by the U.S. government, permitted discounts for larger groups.

17 By contrast, the lower the costs of hotels and restaurants at the destination, the greater is the passenger's tendency to stay longer and reduce the frequency of visits in the future. (See also Mak, 2004, pp. 52-53).

18 As well, as newer and faster planes were able to fly over the vast Pacific Ocean without frequent refueling, the number of stopover and in-transit visitors to Hawaii declined. The number of in-transit passengers (i.e. passengers who do not spend at least one night in Hawaii) fell from roughly 1 million per year in the 1980s and early 1990s to 13,000 in 2008.

${ }^{19}$ However, the CAB did not regulate the frequency and quality of service, thus inducing airlines to engage in non-price competition such as buying more and bigger planes, scheduling more flights, and providing more on-board "free" amenities. For instance, Western Airlines boasted that it served (free) champagne on every Hawaii flight (Ebel and Mak, 1974, p. 36). Aggressive non-price competition dissipated the potential excess profits that airlines could have earned on their protected routes. 
carrier in the Hawaii market. Borrowing a pricing practice on the Mainland, economy fares were introduced on the Hawaii routes in the early 1950s. Then in 1969 and 1970 came the Civil Aeronautics Board's great expansion of five additional carriers: American, Braniff, Continental, TWA, and Western. ${ }^{20}$ Competition among airlines was growing rapidly. Increased competition was good for consumers as it led to lower airfares and better service quality.

Improvements in air transportation services took a heavy toll on travel by ocean liners. Time cost conscious business travelers were the first to switch to air travel. By the early 1960s, most of the passengers on Matson's White ships were vacationers (O'Brien, 2008, p. 257). When the Boeing 747 was introduced into Hawaii service in 1970, less then one-half of one percent of the visitors from North America still arrived by sea (Schmitt, 1977, p. 276). In the same year, Matson terminated its passenger service. ${ }^{21}$ The last sailing of a "White ship" under its new owner in 1978 ended the era of luxury liner travel between the West Coast and Hawaii (O'Brien, 2008, p. 15). It is noteworthy that most of the decline in ship travel came after World War II following the deployment of the more efficient land-based piston engine planes.

Kuznets noted that technical improvements that increase productivity and cheapen prices would "spread to larger areas, overcoming obstacles which may have limited demand in the past." Rapid growth of the industry ensues. We now examine the trend in airfares from the U.S. mainland to Hawaii. While the airfare is not the total cost of a vacation in Hawaii, it is arguably the most important. Demand for long haul travel is highly sensitive to changes in the cost of transportation (Bechdolt, 1970; Oum, Walters and Yong, 1972; and Crouch, 1995). ${ }^{22}$

Economic theory predicts that if an industry (market) is highly competitive, the rate of change in the price of the commodity should reflect the underlying rate of change in the industry's productivity. ${ }^{23}$ However, interstate passenger air transportation in the U.S. was not an open, competitive market until after the early 1980s. In 1938 Congress passed the Civil Aeronautics Act of 1938 creating the Civil Aeronautics Board (CAB) to regulate airfares and airline entry and exit; forty years later in 1978 Congress

${ }^{20}$ For the story of this highly controversial case, see Davies (1972), pp. 557-561, 21 Matson tried but was unsuccessful in its bid to secure CAB authorization to offer scheduled airline service from the West Coast to Hawaii (Davies, 1972, p. 377; Melendy, 2003). One of the reasons for the denial was CAB's concern that Matson's dominance in ocean shipping and its ownership of two of the premier hotels in Hawaii would give it a competitive advantage over Pan Am. Without an airline, Matson sold its four Waikiki hotels to Sheraton in 1959.

22 Biederman (1982, p. 168) notes that it was widely accepted among airline industry officials before deregulation that demand for business travel was price inelastic while that of leisure travel was price elastic and adopted pricing policies accordingly.

23 The mathematical proof is presented in Haites, Mak, and Walton (1974, Appendix G). The productivity measure in Haites, et. al. is "total factor productivity"; however, most estimates of airline productivity, until recently, measure labor productivity (Goodman, 2000). See Apostolides (2005) for differences between the two measures. 
enacted legislation to deregulate the airline industry (Biederman, 1982, Chapter 6). The CAB was abolished in 1985. Airlines were allowed some flexibility in setting airfares beginning in 1976, and they could set any price they desired after 1983 (Biederman, 1982, Chapter 6). Hence, airfares on the Hawaii route between 1938 and 1983 were not "market" prices but were regulated prices. Nonetheless, airfares, adjusted for inflation, fell in the U.S. even before deregulation, reflecting the decline in the cost of supplying air transportation services (Goodman, 2000, Chart 4, p. 44; Morrison and Winston, 1995, Figure 2-3, p. 11).

Table 11.1 presents nominal and real (1982-1984=100) roundtrip San Francisco to Honolulu airfares between 1936 and 1977 during the regulated era. These are based on the cheapest available class of fares available to individual consumers, and hence are not constant service quality prices. In 1977, the cheapest nominal round trip airfare was only one-third that in 1936. Adjusted for inflation, it was less than one-twelfth (8 percent) the fare in 1936. 
Table 11.1

Trends in the Cheapest Nominal and Real Roundtrip Airfares and Flight Times between San Francisco and Honolulu: 1939-1977

(Real Airfares in 1982-1984 Prices)

\begin{tabular}{|c|c|c|c|c|c|c|}
\hline Year & $\underline{\text { Airfare }}$ & $\underline{\text { Fare Class }}$ & $\underline{\text { Real Airfare }}$ & Flying Time & Plane & $\underline{\text { Seats (circa) }}$ \\
\hline 1936 & $\$ 712$ & First & $\$ 5,120$ & 20:00 & M-130 & 28 \\
\hline 1937 & 712 & “ & 4,450 & “ & “" & \\
\hline 1938 & 712 & “ & 5,050 & “" & “ & \\
\hline 1939 & 556 & “ & 4,000 & $17: 30$ & B -314 & 74 \\
\hline 1940 & 500 & “ & 3,571 & “" & “" & \\
\hline 1941 & 500 & “" & 3,401 & “ & “" & \\
\hline 1942 & 500 & “ & 3,067 & “ & “ & \\
\hline 1943 & 500 & “ & 2,890 & “ & “ & \\
\hline 1944 & 500 & “ & 2,841 & “ & " & \\
\hline 1945 & 500 & “" & 2,778 & “ & " & \\
\hline 1946 & 350 & “ & 1,795 & $11: 45$ & DC-4 & 40 \\
\hline 1947 & 243 & “ & 1,090 & “" & “" & \\
\hline 1948 & 270 & "“ & 1,120 & “" & "“ & \\
\hline 1949 & 288 & “" & 1,210 & $9: 25$ & B-377 & 60 \\
\hline 1950 & 288 & “ & 1,195 & “ & “ & \\
\hline 1951 & 288 & “" & 1,108 & “" & “" & \\
\hline 1952 & 250 & Economy & 943 & “ & “ & \\
\hline 1953 & 250 & “ & 936 & “ & " & \\
\hline 1954 & 250 & “" & 929 & “ & " & \\
\hline 1955 & 250 & “" & 933 & “" & “" & \\
\hline 1956 & 250 & "“ & 919 & “" & "“ & \\
\hline 1957 & 250 & “ & 890 & “ & “" & \\
\hline 1958 & 266 & “ & 920 & $8: 25$ & DC-7C & 110 \\
\hline 1959 & 266 & “" & 914 & “" & “ & \\
\hline 1960 & 266 & “ & 899 & “ & “ & \\
\hline 1961 & 266 & “" & 890 & “ & " & \\
\hline 1962 & 266 & “ & 881 & 4:55 & Boeing 707 & 180 \\
\hline 1963 & 200 & Thrift & 654 & “ & “ & \\
\hline 1964 & 200 & Thrift: Weekday & 645 & “" & “ & \\
\hline 1965 & 200 & “ & 635 & “ & “ & \\
\hline 1966 & 200 & “" & 617 & “" & “" & \\
\hline 1967 & 200 & “ & 599 & “ & “ & \\
\hline 1968 & 200 & “ & 575 & “" & “" & \\
\hline 1969 & 170 & “" & 463 & “ & “" & \\
\hline 1970 & 170 & “" & 438 & “" & “" & \\
\hline 1971 & 196 & “" & 484 & $4: 55$ & Boeing 747 & $360-460$ \\
\hline 1972 & 200 & “" & 478 & 5:02 & “" & \\
\hline 1973 & 200 & “ & 450 & “ & “ & \\
\hline 1974 & 232 & “" & 471 & 4:58 & “" & \\
\hline 1975 & 232 & “ & 431 & “ & “ & \\
\hline 1976 & 232 & “" & 408 & “ & “ & \\
\hline 1977 & 238 & “ & 393 & “ & “ & \\
\hline
\end{tabular}

Notes: Airfares were deflated using the U.S. consumer price index (CPI-U), 1982-84=100, published by the U.S. Census Bureau.

Source: Airfares, flying time, and planes from Schmitt, 1977, pp.468-469. Seating capacity from footnotes above. 
With deregulation in 1978 came the proliferation of fare categories. Table 11.2 presents weighted $^{24}$ airline passenger yields (i.e. average ticket revenue per passenger mile) on domestic westbound flights to Hawaii between 1982 and 1997 using data (OD1A series) from the U.S. Department of Transportation. ${ }^{25}$ Recalling that airlines could fully set their own fares beginning in 1983, nominal yields between the U.S. mainland and Hawaii rose by 6 percent between 1982 and 1997 but real yields fell by 35 percent between the two years.

Table 11.2

Trends in Weighted Airline Passenger Yields between the U.S. Mainland and Hawaii: 1982-1997 (in cents per passenger mile)

\begin{tabular}{ccc} 
Year & Nominal Yield & Real Yield $(1982-1984=100)$ \\
\cline { 2 - 3 } 1982 & 6.6 & 6.8 \\
1983 & 6.1 & 6.1 \\
1984 & 6.5 & 6.3 \\
1985 & 7.0 & 6.5 \\
1986 & 6.4 & 5.8 \\
1987 & 7.3 & 6.4 \\
1988 & 7.3 & 6.2 \\
1989 & 7.2 & 5.8 \\
1990 & 7.3 & 5.6 \\
1991 & 7.3 & 5.4 \\
1992 & 7.1 & 5.1 \\
1993 & 7.1 & 4.9 \\
1994 & 7.4 & 5.0 \\
1995 & 7.2 & 4.7 \\
1996 & 6.9 & 4.4 \\
1997 & 7.0 & 4.4
\end{tabular}

Source: Data from internal records kindly supplied by Dr. Eugene Tian, State of Hawaii Department of Business, Economic Development and Tourism (DBEDT).

Table 11.3 summarizes the average annual percentage changes in visitor arrivals and real airfares (mostly) at 10-year intervals since 1930. For the years for which we have data, real airfares for travel between the mainland and Hawaii fell. The annual percentage rate of decrease was greater right after WWII when the DC-4 and other piston engine planes were introduced, followed by slackening. The rate of fare decline picked up again during the decade of the 1960s when the era of jet travel began. The

${ }^{24}$ Weighted by the share of seats from various U.S. mainland cities; only fares paid by paying passengers were included in the calculations. The estimates, which have not been previously published, were kindly supplied to the authors by Dr. Eugene Tian of the State of Hawaii, DBEDT.

25 The Department of Transportation uses a sample of airline tickets. Trends in airline passenger yields are commonly used to measure trends in airfares (See Morrison and Winston, 1995, Chapter 2). 
introduction of the Boeing 747 and other wide-body jets after the 1970s were the last major technological change in airplanes that were of economic importance (Goodman, 2000). ${ }^{26}$

Table 11.3

Average Annual Percentage Change in Visitor Arrivals and Real Airfares

\begin{tabular}{lcc}
$\begin{array}{lc}\text { Period } \\
1922-30\end{array}$ & \% Change in Visitors & \% Change in Airfares \\
\cline { 2 - 3 } $1930-40$ & 9.2 & $-7.9(1936-40)$ \\
& 5.6 & Tourism Suspended, 1942-45, Due to WWII* \\
$1946-50$ & 34.6 & -7.5 \\
$1950-60$ & 20.8 & -2.7 \\
$1960-70$ & 19.7 & -6.5 \\
$1970-80$ & 8.7 & $-1.3(1970-77)$ \\
$1980-90$ & 5.6 & $-2.6(1982-90)$ \\
$1990-2000$ & .4 & $-3.4(1990-97)$ \\
$2000-2009$ & -.5 & --
\end{tabular}

Note: *Attack on Pearl Harbor (Honolulu) occurred on December 7, 1941.

Source: Percentage change in airfares calculated from Table 11.1 for years before 1978 and from Table 11.2 for 1982-1997. Visitor arrivals from Table 11.1A, Appendix.

Goodman (2000, p. 43) notes that in the U.S., "Despite all the benefits of competition, output per employee advanced much more slowly after 1978, when ongoing changes to the aircraft were not so economically meaningful." Real airfares continued to decline after the 1970s but not as steeply as before. $^{27}$ The timing of changes in real airfares in the Hawaii market corresponds roughly-roughly, because other factors also influenced airfares-- to changes in labor productivity in the U.S. air transportation industry. ${ }^{28}$ Visitor arrivals also grew faster before 1970 than after 1970. The period between the end of WWII and (around) 1970 when the annual rates of tourism growth averaged in the double digits was, arguably, the Golden Age of travel to Hawaii.

26 Kuznets (1930, p. 30-33) noted that "the number of important inventions within an industry with an unretarded supply of raw materials tends to diminish with time." The airline industry benefited from other technological improvements besides improvements to the aircraft, among the most important include the computer reservation system first introduced by United Airlines and American Airlines in 1976 (Morrison and Winston, 1995, pp. 61-62). The development of the hub-and-spokes system in the early 1980 s, a by-product of airline deregulation, also raised airline productivity as it helped to raise load factors (Goodman, 2000, p. 43).

27 Economic recession in the early 1970s slowed the deployment of the Boeing 747 until late in the decade and two energy crises during the 1970s raised the cost of air service provision.

${ }^{28}$ It is not unreasonable to assume productivity change in air transportation in the Hawaii market to be highly correlated to productivity change in the entire U.S. 
The revolution in air transportation after 1959 ended the era when Hawaii was a vacation spot for the affluent. Some called what followed "mass tourism", others "the democratization of travel." Dr. Richard R. Kelley, Board Chairman of his family-owned Hawaii hotel chain, Outrigger Enterprises Inc., recalled the dramatic transformation of Hawaii tourism from the ' 50 s to the ' 70 s this way: ${ }^{29}$

I remember back in '51, I don't think we even had 10,000

visitors at that point...Back in the ' 40 s and ' $50 \mathrm{~s}$, everybody

came in by boat. HVB (Hawaii's Visitors Bureau) had a tug

rented and we'd go offshore and greet people. It was all

individual treatment. Reservations were made and confirmed

by mail with a three-cent stamp. But by 1970 larger number

of tourists started to come. Jet planes were soon followed by

the jumbo jet. All of a sudden we were dealing with an entirely

different level. These weren't individuals, this was the day of

mass tourism. The only way to get a cheap airfare was to book

a packaged tour. Everybody was doing that. Suddenly we had

200 people in our lobby all at once, then you have nothing for a

couple of days, then another 200 show up. We had to get into

sales and marketing, working with wholesale travel companies.

It was just a rapid evolution of the business.

In retrospect, the timing of the CAB's decision to adopt a more competitive market structure was directly linked to the expected increase in demand for air travel in the Pacific stemming in large part to technical advances in aircrafts. ${ }^{30}$ It also provided entrepreneurs the incentive to develop new supporting tourism businesses (e.g. tour wholesalers), and induced the entry of national/global hotel chains such as Sheraton (in 1959) and Hilton (in 1961) to Hawaii (Allen, 2004, Chapter 2). As noted by Kelley, progress in air transportation also led to consumer product innovation (e.g. the rise of pre-paid group package tours).

29 The Honolulu Advertiser (2004), p. C3. His father, Roy Kelley, and Founder of Outrigger, was instrumental in building large numbers of affordable hotels for the "common man." (Allen, 2004, Chapter 5).

30 Between 1959 and 1965, the number of air travelers between the U.S. and the Far East and Oceania experienced the fastest growth rate of any of the world's routes (Davies, 1972, p. 557). World War II also raised awareness by Americans of Hawaii and Pearl Harbor and the greater acceptance of air transportation as a mode of travel. 
In 1951, more than half (52.3\%) of all westbound (i.e. mostly North American) visitors to Hawaii were from California. ${ }^{31}$ By 1975, that percentage had fallen below 25\% (Schmitt, 1977, p. 274).

Geographically, the market for Hawaii travel in North America was expanding eastward away from the West Coast. Falling (real) airfares and time cost of travel expanded the geographic market for Hawaii tourism. It also induced people to take shorter but more frequent trips. The percentage of repeat westbound visitors grew from 22 percent in 1951 to nearly 40 percent by 1975 (Schmitt, 1977, p. 274). The rise in repeat visitation was greatest after the introduction of jet plane travel in 1959. At the same time, the average length of stay of westbound visitors to Hawaii fell from 25 days in 1951 to less than 11 days in 1975 (Schmitt, 1977, p. 276).

Even a cursory examination of Table 11.1A in the Appendix reveals the stunning growth in the volume of tourists since 1959. Visitor arrivals increased from 243,000 in 1959 to 1.7 million in 1970, to 3.9 million in 1980, and 6.7 million in 1990. Over a span of 31 years between 1959 and 1990, there was only one year (1980) in which the visitor count fell below that of the previous year. And that decline was a small one, less than one percent. Hawaii was seemingly immune from negative national and international shocks.

Tourism's growth rate slackened dramatically after 1970, but not because Hawaii had reached its physical or social carry capacity as Butler had hypothesized. Hawaii remained one of the most desired destinations to visit. In 1999, the National Geographic Traveler magazine included Hawaii in its list of "50 Places of a Lifetime: The World's Greatest Destinations." In 2004, Travel Weekly named Hawaii the "Best Overall Destination in America." A telephone poll of over 1,000 American adults commissioned by the Associated Press in 2005 found that Hawaii was their top vacation choice if money were no problem (Mak, 2008, p. 1). Kirk Smith, senior fellow in the environmental program at the East-West Center (Honolulu) opined that overall, "Hawaii's natural environment is in great shape (relative to all other places inhabited by human beings", even in and around Honolulu, our only big city." (Smith, 1993; also quoted in Mak, 2008, p. 143). Surveys of resident sentiment on tourism taken over many years do not indicate that Hawaii has reached or exceeded its tourism social carrying capacity either (Mak, 2008, p. 212; and Market Trends Pacific and John M. Knox \&Associates, Inc., Vol. II, 2008). The latest survey done in 2009 found that $78 \%$ of the state's respondents agreed that "overall, tourism has brought more benefits than problems to the State" while $21 \%$ of the respondents disagreed (OmniTrak, 2010). ${ }^{32}$ Historically, most of Hawaii's residents have expressed a strong sense of the "Aloha Spirit" (i.e. hospitality), rather than hostility, toward tourists as individuals (Market Trends Pacific, Inc. and John M. Knox \& Associates, Inc., 2003, p. 57).

\footnotetext{
${ }^{31}$ Visitors from North America accounted for 88 percent of all visitor arrivals in Hawaii in that year. 32 In $2007,71 \%$ responded positively. Surveys have generally found Native Hawaiians to be least supportive of tourism growth.
} 
Indeed, even as the rate of tourism growth was slowing in the 1970s, the state's tourism carrying capacity was growing as the outer islands of Maui, Kauai, and Hawaii (the Big Island) were just beginning to open up to mass tourism development (Mak, 2008, Chapter 8).

\subsubsection{0 to the Present: Maturity and Stagnation}

Hawaii's visitor industry struggled during the 1990's. In the two decades since 1990, volatility replaced sustained growth.

There were a number of plausible reasons why tourism was in the doldrums in those years. Most of the factors were transitory. A prolonged economic recession in California, the first Gulf War in 1991, the collapse of Japan's economic bubble in the same year, the devastation of Kauai by Hurricane Iniki in September, 1992, and an airfare war among the major airlines on the U.S. mainland during the summer of 1992 which excluded Hawaii all combined to create the Perfect Storm that slammed Hawaii's tourist industry for three consecutive years at the start of the 1990's. The Asian Financial Crisis of 1997-1998 discouraged foreign travel to Hawaii (-2\% in 1997 and -10.1\% in 1998). A succession of negative shocks also occurred after 2000. The decline in tourist arrivals in 2001 can readily be blamed on a mild U.S. economic recession that began earlier in the year, the terrorist attacks on September 11 (which shut down air travel in the U.S. for several days) and the subsequent Coalition invasion of Afghanistan. The decline in 2003 can be attributed to the Iraq War and the outbreak of the Severe Acute Respiratory Syndrome (SARS) in Asia. A recession in the U.S., which started in December of 2007, followed by a severe global financial crisis produced a sharp decline in demand for travel to Hawaii and to just about everywhere else in 2008 and 2009.

There was much discussion among local observers in Hawaii whether the tourism doldrums of the 1990's were only transitory. Surveys of visitors showed no sudden and sharp decline in satisfaction with their travel experiences in Hawaii. Indeed, in 2006, Hawaii recorded the greatest number of visitor arrivals in its history (7.5 million). Each of the two preceding years also set an all-time high record in visitor arrivals. But just about everyone agreed that Hawaii had become a mature destination, and probably for quite some time. The average annual rate of growth of tourist arrivals had fallen from double digits in the ' 60 s to a single digit after that. Moreover, most (indeed nearly 60 percent) of Hawaii's tourists were repeat visitors. Among U.S. Mainland visitors roughly two-thirds had been to Hawaii before and many were on their $4^{\text {th }}, 5^{\text {th }}$, or more trips. By comparison, in the 1950 's, roughly 75 percent of all the visitors were first time visitors. Waikiki, still the flagship of Hawaii's tourist industry, looked somewhat shabby and in need of major physical renovation. Hawaii was losing market share to other tourist destinations, and no new major markets appeared on the horizon.

\subsection{Competition from Other Destinations}


H. Peter Gray (1970) once characterized tourism as either "sunlust" travel or "wanderlust" travel. For most of its history Hawaii has been a premier "sunlust" destination, with many, and indeed growing number of, destinations around the world offering good substitutes. Kuznets recognized the importance of competition in causing the slackening or decline of industries.

In 2008, U.S. and Japanese visitors comprised $84 \%$ of all visitors (excluding those arriving by cruise ships) to Hawaii (State of Hawaii, DBEDT, 2009). How competition from other destinations has affected those two groups of visitors over time reveals much about the impact of competing destinations on Hawaii's destination lifecycle.

In 1983 572,000 Japanese visitors arrived in Hawaii, representing 13.5 percent of all Japanese trips to foreign destinations. Hawaii's market share fluctuated from year to year, usually between 13 percent and 14 percent, but did not exhibit a discernible downward trend until after 1995 (Figure 11.4).

Figure 11.4

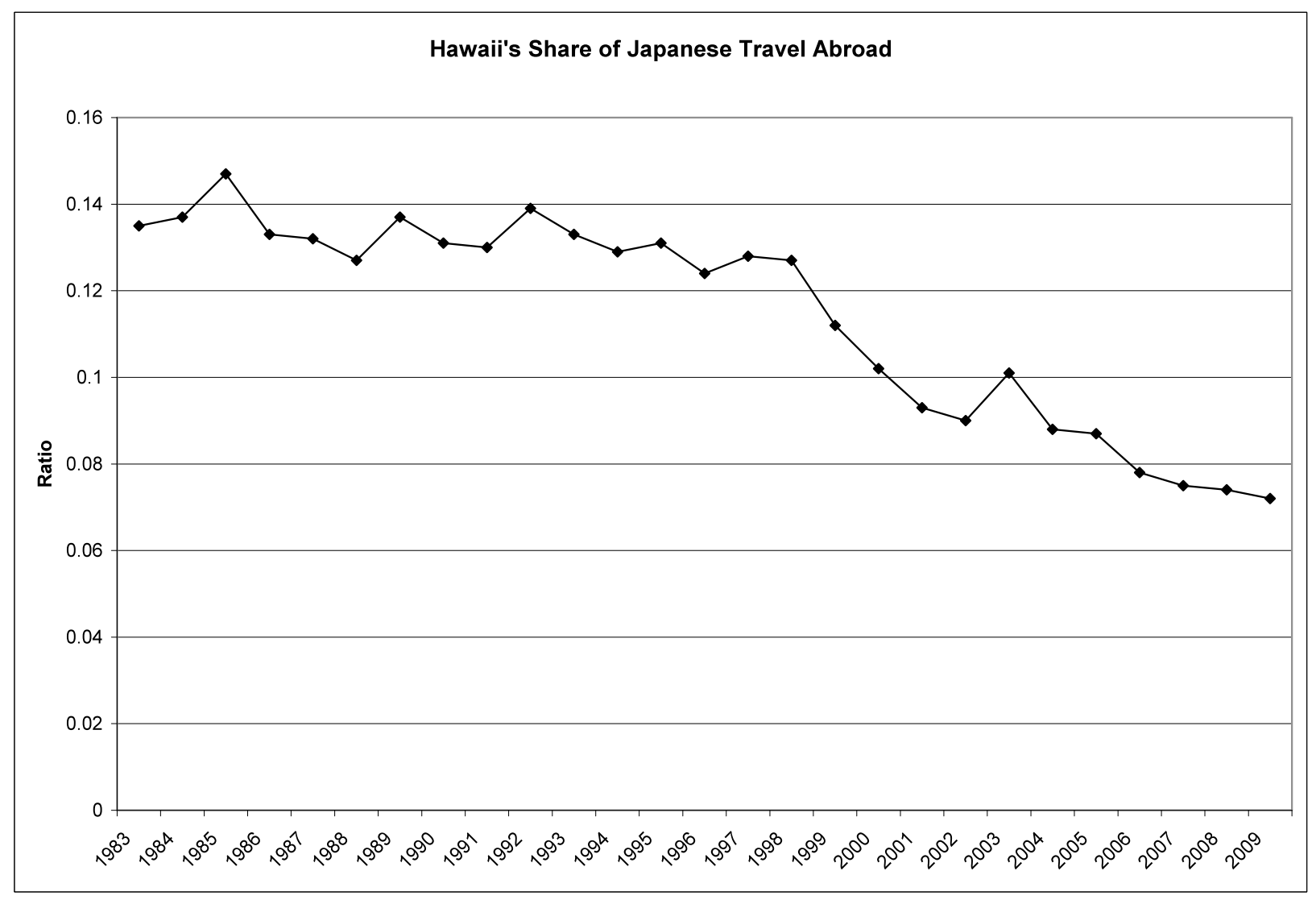

Sources: Japanese outbound data from JTB Report (various years), JATA-NET (on-line), and Travel Journal; Japanese arrivals in Hawaii from State of Hawaii Department of Business, Economic Development and Tourism.

Thereafter, it would never reach 13 percent again. Japanese travel to Hawaii peaked in 1997 at 2.152 million arrivals. At Japan's airports, one in eight among Japanese overseas travelers was headed to 
Hawaii. After 1997, Hawaii's share of Japanese outbound travel would fall nearly every year reaching the current percentage of 7.2 percent (2009). ${ }^{33}$ While the Japanese travel to Hawaii has declined since 1997 , the total number of Japanese outbound travelers (to all international destinations) peaked in 2000 at 17.8 million. ${ }^{34}$ In 2006, Hawaii's market share of Japanese outbound travel was 7.8 percent when 17.53 million Japanese traveled overseas, the second highest total number of departures in any year. In 2009, 1.117 million Japanese tourists visited Hawaii, more than one million less than during the peak year of 1997 (State of Hawaii, DBEDT)). Increasingly, the Japanese are finding other destinations more attractive. ${ }^{35}$ The story of American travel to Hawaii is somewhat different from that of the Japanese. Here, we employ the ratio of American (domestic) travel to Hawaii and U.S. travel overseas (excluding Canada and Mexico) to represent the trend in the relative attractiveness of Hawaii versus other long-haul (foreign) destinations. Figure 11.5 shows the ratio between 1983 and 2009. ${ }^{36}$

${ }^{33}$ Except in 2003. Japan Travel Bureau (various years); Travel Journal (various years); JATA-NET at http://www.jata-net.or.jp/English/materials/materials index.htm

$3410.2 \%$ of these travelers were bound for Hawaii. The numbers would fall to 17.29 million in 2007 and 15.44 million in 2009 .

35 In 2008, 58 percent of all Japanese visitors to Hawaii were repeat visitors (average of 3.77 trips) (State of Hawaii, DBEDT, 2009, p. 43). Surveys of Japanese satisfaction with their Hawaii vacations indicate that about two-thirds of the respondents would very likely recommend Hawaii to their friends and relatives but less than half would likely return to Hawaii themselves in the next five years. The most frequently given reason for not returning soon is the desire to visit other destinations. (State of Hawaii, DBEDT, 2008, pp. 8-13).

${ }^{36}$ Aggregate U.S. outbound travel data are not available for years before 1983. 
Figure 11.5

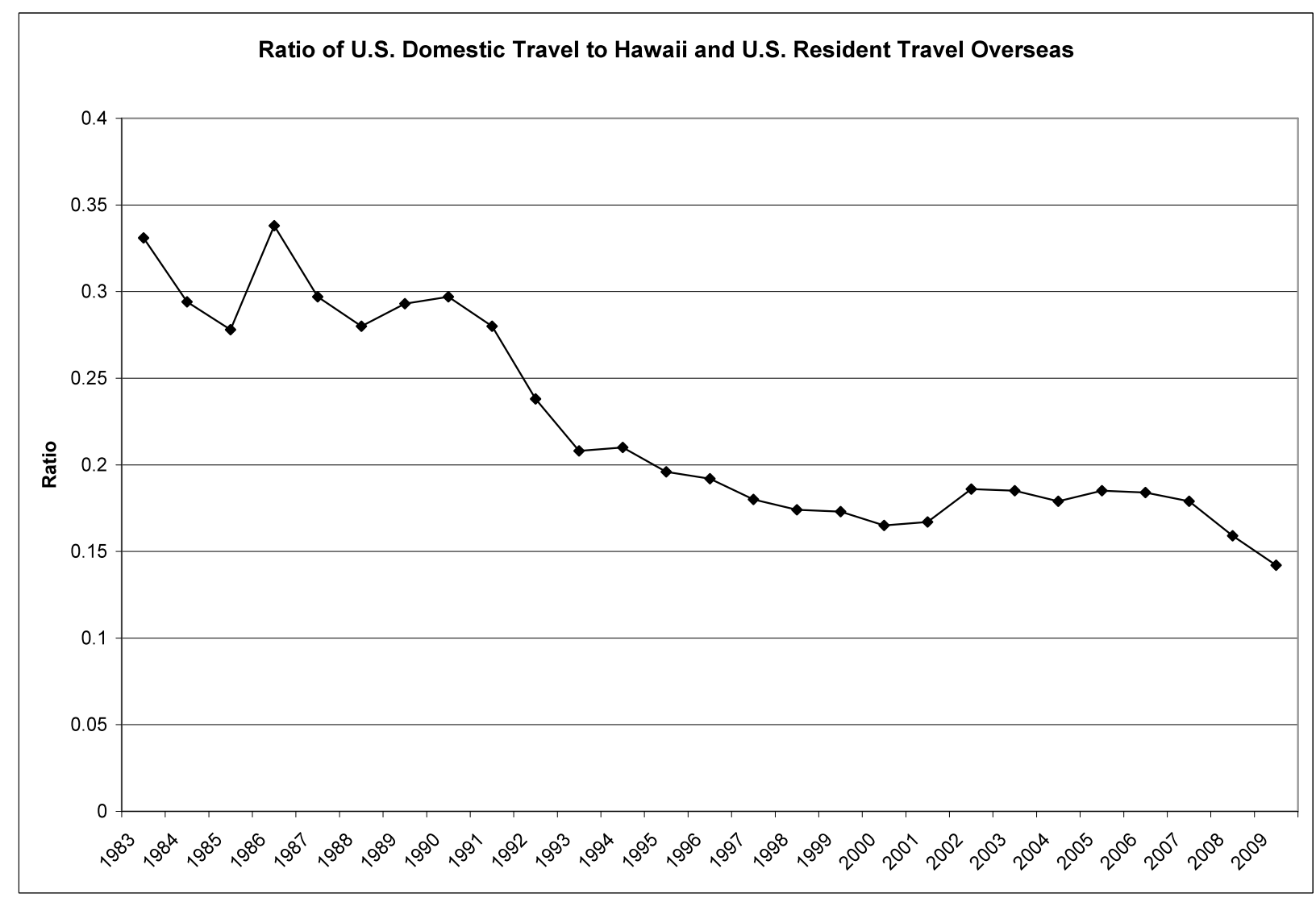

Sources: U.S. foreign outbound travel data from U.S. Department of Commerce, Office of Travel and Tourism Industries;1983-1989 obtained through personal communication; U.S. domestic visitor arrivals in Hawaii from the State of Hawaii Department of Business Economic Development and Tourism.

In the 1990s, the ratio of U.S. domestic travel to Hawaii to U.S. resident overseas foreign travelexcluding Canada and Mexico- - began a long decline, indicating that foreign destinations had become relatively more attractive than Hawaii. For a few years after the terrorist attacks of 9/11 (2001), Hawaii once again became relatively more attractive to Americans due to growing apprehension of foreign travel. That apprehension appears to have abated after 2005. ${ }^{37}$ Still, unlike Japanese travel to Hawaii, the number of U.S. (domestic) visitors to Hawaii continued to rise until 2007 after a brief reversal in the early 1990s. A review of both U.S. and Japan markets indicates that competition from other destinations has had a significant impact on the growth of tourism in Hawaii since the 1990s.

37 The temporary gain in popularity of Hawaii vis-à-vis other overseas destinations after 9/11 is discussed in Bonham, et. al. (2006). 


\subsection{Conclusion}

This article shows that the history of tourism evolution in Hawaii fits well Butler's TALC, even if the path has not been smooth. Throughout its lengthy history as a world-class tourist destination, Hawaii has been buffeted by numerous external shocks including wars, terrorist attacks, government travel regulations (in the U.S. and elsewhere), business cycles, financial crises, contagious disease outbreaks, and natural disasters, but most of these shocks were transitory. The underlying expansion path is the S-shaped curve described by Butler. However, and contrary to Butler, for Hawaii the more important factor in shaping that curve was the pace of progress in air transportation technology and not the islands' "carrying capacity".

Tisdell (2005, p. 233) offers another reason for the eventual slowdown in the expansion of tourist destinations. He suggests (p. 233) that initial rapid growth of visitor arrivals may be the result of the realization of latent demand by some people who wished to visit but could not, and once satisfied "future demand may depend on such factors as population growth and repeat visits, which may be few." Tisdell's latent demand hypothesis is not incompatible with the technical change hypothesis advanced here. In the case of Hawaii, latent demand could not be satisfied until technical progress in air transportation made it possible at an affordable cost. Technical progress that reduces the cost of travel can also increase the size of the potential travel market, including the creation of new markets, thus staving off retardation. As technical progress slackens, the other factors mentioned by Tisdell may dominate to slow the growth of the destination.

American economic history reminds us that economies, over time and as a result of technological progress and changes in factor proportions, experience changes in their comparative advantage that can lead to changes in their industrial structure (Hughes and Cain 2003, pp. 393-394). The economic history of Hawaii provides an excellent illustration of how changes in transportation technology has changed Hawaii's comparative advantage thus altering the structure of its economy over time (La Croix, 2001; Hitch, 1992; Morgan, 1948). At any time in Hawaii’s history, a few industries were dominant. In succession, the sandalwood trade of the early $19^{\text {th }}$ century was replaced by the whaling industry in the middle of the $19^{\text {th }}$ century followed by sugar and pineapple production during the latter $19^{\text {th }}$ and early $20^{\text {th }}$ centuries, and finally defense and tourism. On the eve of America's entry into World War II (1940), the sugar industry produced $\$ 55$ million in export revenues; pineapple, $\$ 46$ million; U.S. government military expenditures in Hawaii, \$45 million; while tourism produced only \$12 million (Schmitt, 1977, p. 165). In 2005 tourism generated $\$ 11.9$ billion in external earnings compared to $\$ 92.5$ million for sugar, $\$ 113.4$ million for pineapple, and $\$ 5.0$ billion for U.S. military expenditures (DBEDT, 2008a, Table 13.01). Innovation in aviation technology and geopolitics (i.e. the growing importance of Asia and the Pacific in global affairs) helped to transform Hawaii's comparative advantage from commodity production (sugar 
and canned pineapple) to service production (tourism and U.S. military presence). The rise of tourism to its current dominant economic position in Hawaii was most crucially due to technical advances in air transportation. We have no reason to believe that Hawaii's comparative advantage may not shift again from tourism to something else in the future.

The main lesson from the TALC is that tourism once it takes off can make an increasing contribution to the economic growth of an area, but eventually becomes a relatively diminished force. Fortunately, for most destinations, tourism is not the only industry contributing to economic growth. Kuznets noted that it is typical for industry leadership to shift from one industry to another over time. Even long before tourism goes into the final stage of absolute decline, the tourism industry may have been experiencing a relative decline for some time as new industries grow at faster rates. In Hawaii, tourism's (direct) share of the gross domestic product peaked in 1988 at 24.7 percent and has been in decline ever since (State of Hawaii, DBEDT, 2000, Tables 7.20 and 13.02). ${ }^{38}$ Butler suggested that management (i.e. government) intervention may be able to slow the pace or even prevent tourism's decline (Butler, 1980 and Butler, 2006a, p. 285). Management intervention comes at a cost. Who should bear the cost? And will the expected benefit from intervention be worth its cost? The optimum tourism development policy is one that examines tourism not in isolation but as part of a larger economy.

38 In 2008, tourism's contribution (direct + indirect) represented 16.9 percent of Hawaii's gross domestic product, down from 19.9 percent in 2002 . When visitor arrivals reached an all-time high in 2006, tourism's share of the state's gross domestic product was 18.9 percent. The rest of Hawaii's economy has been growing faster than tourism (State of Hawaii, 2008a). Indeed, if we employ real tourism expenditures in Hawaii as a measure of destination size, tourism in Hawaii has declined absolutely for two decades. 


\section{References}

Allen, RC. (2004). Creating Hawaii tourism, a memoir. Honolulu: Bess Press.

Apostolides, AD. (2005). Impacts of productivity changes in air transportation on profits, prices and labor compensation: 1990-2001. Washington D.C.: Research \& Innovative Technology Administration (RITA), U.S. Department of Transportation at

http://www.bts.gov/publications/journal_of transportation_and_statistics/volume_09_number_01/html/pa per 01/index.html [accessed 7 September 2010]

Bechdolt, B (1973). "Cross-sectional travel demand functions: U.S. visitors to Hawaii, 1961-1970.” Quarterly Review of Economics and Business, Vol. 13, No. 2, Winter, pp. 37-47.

Biederman, P (1982). The U.S. airline industry, end of an era. New York: Praeger Publishers.

Bonham, C, C Edmonds, \& J Mak (2006). "The impact of 9/11 and other terrible global events on tourism in the U.S. and Hawaii." Journal of Travel Research, 74 (2), pp. 409-438.

Burns, AF (1934). Production trends in the United States since 1870. New York: National Bureau of Economic Research.

Butler, RW (ed.) (2006). The tourism area life cycle: applications and modifications. Vol. 1, Buffalo and Toronto: Channel View Publications.

Butler, RW (ed.) (2006a). The tourism area life cycle: conceptual and theoretical issues. Vol. 2, Buffalo and Toronto: Channel View Publications.

Butler, RW (1998). "Still peddling along. The resort cycle two decades on.” Progress in Tourism and Hospitality Research. CAUTHE Conference, Gold Coast.

Butler, RW (1980). "The concept of the tourist area cycle of evolution: implications for the Management of Resources. " Canadian Geographer, 24, pp. 5-12.

Cohen, S (2001). The pink palace. Missoula, Mt: Pictorial Histories Publishing Company, June.

Crampon, LJ (1976). Hawaii's visitor industry, its growth and development. Honolulu: University of Hawaii, School of Travel Industry Management.

Crouch, GI (1995). “A meta-analysis of tourism demand.” Annals of Tourism Research, Vol. 22, No. 1, pp. 103-118. 
Davies, REG (1972). Airlines of the United States since 1914. London: Putnam.

Ebel, R and J Mak (1974). Current issues in Hawaii's economy. Honolulu: Crossroads Press, Inc., June.

Goodman, WC (2000). “Transportation by air: job growth moderates from stellar rates." Monthly Labor Review, March, pp. 34-47 at http://www.bls.gov/opub/mlr/2000/03/art3full.pdf [accessed 7 September 2010.]

Gort, M and S Klepper (1982). "Time paths in the diffusion of product innovations." The Economic Journal, 92, September, pp. 630-653.

Gray, HP (1970). International travel-international trade. Lexington, Mass.: Lexington Books, D.C. Heath $\& C o$.

Gronau, R (1970). “The effect of travel time on the demand for passenger transportation," Journal of Political Economy, Vol. 78, No. 2, March/April, pp. 377-394.

Haites, EF., J Mak \& GM Walton (1974). Western river transportation, the era of early internal development, 1810-1860. Baltimore: Johns Hopkins University Press.

Hitch, TK (1992). Islands in transition: the past, present and future of Hawaii's economy. Honolulu: First Hawaiian Bank, distributed by the University of Hawaii Press.

The Honolulu Advertiser (2004). "Leadership corner," November 15, p. C3.

Hughes, J and LP Cain (2003). American economic history. $6^{\text {th }}$ edition, Boston: Addison Wesley.

Japan Travel Bureau (JTB) (Annual). JTB report: All about Japanese Overseas Travelers, Tokyo: JTB.

JATA-NET (2009).Overseas Trends in Inbound-Outbound Travel at http://www.jata-net.or.jp/English/materials/materials_index.htm [accessed 7 September, 2010]

Jovanovic, B and GM MacDonald (1994). "The life cycle of a competitive industry." The Journal of Political Economy, Vol. 102, No. 2, April, pp. 322-347.

Klepper, S (1996). "Entry, exit, growth, and innovation over the product life cycle." American Economic Review, Vol. 86. No. 3, June, pp. 562-583.

Klepper, S and E Graddy (1990). "The evolution of new industries and the determinants of market structure.” Rand Journal of Economics, 21, Spring, p. 24-44. 
Kuznets, SS. (1930). Secular movements in production and prices, their nature and their bearing upon cyclical fluctuations. Boston and New York: Houghton Mifflin Company.

La Croix, S (2001). "Economic history of Hawaii." EH:Net Encyclopedia, at http://eh.net/encyclopedia/article/lacroix.hawaii.history [accessed 7 September, 2010].

Mak, J (2008). Developing a dream destination: tourism and tourism policy planning in Hawaii. Honolulu: University of Hawaii Press.

Mak, J (2004). Tourism and the economy: understanding the economics of tourism. Honolulu: University of Hawaii Press.

Marketing Trends Pacific and John M. Knox \& Associates, Inc. (2008). 2007 survey of resident sentiments in Hawaii. Volumes I and II, Prepared for the Hawaii Tourism Authority, Honolulu: HTA, January at http://www.hawaiitourismauthority.org/index.cfm?page=1rp reports [accessed 7 September 2010].

Market Trends Pacific and John M. Knox \& Associates, Inc. (2003). 2002 survey of resident sentiments on tourism in Hawaii, analysis and report. Prepared for the State of Hawaii, Department of Business, Economic Development and Tourism, and the Hawaii Tourism Authority, April, at http://www.hawaiitourismauthority.org/documents upload_path/reports/HTAPLA-Report-04-01-2003.pdf [accessed 7 September, 2010].

Martin, BS and M Uysal (1990). "An examination of the relationship between carrying capacity and the tourism lifecycle: management and policy implications." Journal of Environmental Management, 31, pp. 327-333.

Melendy, HB (2003). "The competition for trans-Pacific air routes to Hawaii, 1945-1959." The Hawaiian Journal of History, vol. 27, pp. 199-216 at

http://evols.library.manoa.hawaii.edu/bitstream/10524/623/2/JL37203.pdf [accessed 7 September 2010]

Morgan, T (1948). Hawaii: a century of economic change, 1778-1876. Cambridge: Harvard University Press.

Morrison, S and C Winston (1995). The evolution of the airline industry. Washington D.C.: The Brookings Institution.

O’Brien, D (2008). The white ships, 1927-1978. Victoria, British Columbia, Canada: Pier 19 Media. 
OmniTrak, Inc. (2010). Resident sentiment survey. Prepared for the Hawaii Tourism Authority, Honolulu: February, 12 at http://www.hawaiitourismauthority.org/index.cfm?page=1rp reports [accessed 7 September 2010].

Oum, TH, WG Walters II \& J Yong (1992). "Concepts of price elasticities of transport demand and recent empirical estimates." Journal of Transport Economics and Policy, Vol. XXVI, No. 2, pp. 139-154.

Rosenberg, N (1972). "Factors affecting the diffusion of technology." Explorations in Economic History, Vol. 10, pp. 3-34.

Schmitt, RC (1977). Historical statistics of Hawaii. Honolulu: The University Press of Hawaii.

Smith, KR. (1993). “Are we adequately protecting our environment?” in Randall W. Roth, ed., The Price of Paradise, Vol. 2, Honolulu: Mutual Publishing, pp. 259-263.

State of Hawaii Department of Business, Economic Development and Tourism (DBEDT) (2009). 2008 annual visitor research report. Honolulu: $D B E D T$ at http://hawaii.gov/dbedt/info/visitorstats/visitor-research/ [accessed 7 September, 2010]

State of Hawaii Department of Business Economic Development and Tourism (DBEDT) (2008). 2007 visitor satisfaction \& activity report. Honolulu: Research and Economic Analysis Division, $D B E D T$ at http://hawaii.gov/dbedt/info/visitor-stats/visitor-research/ [accessed 7 September 2010].

State of Hawaii Department of Business Economic Development and Tourism (DBEDT) (2008a). 2008 State of Hawaii data book, Honolulu: DBEDT at http://hawaii.gov/dbedt/info/economic/databook/db2008/ [accessed 7 September 2010].

State of Hawaii Department of Business Economic Development and Tourism (DBEDT) (2000). 2000 State of Hawaii data book. Honolulu: DBEDT at http://hawaii.gov/dbedt/info/economic/databook/db2000/ [accessed 7 September 2010].

State of Hawaii Department of Business, Economic Development and Tourism (DBEDT) (1999).

"Tourism looks to the future," Hawaii’s Economy, Honolulu: DBEDT, July at http://hawaii.gov/dbedt/info/economic/data_reports/hawaii-econ/he7-99.pdf [accessed 7 September 2010].

Tisdell, CA (2005). Economics of environmental conservation. $2^{\text {nd }}$ edition, Northampton, MA: Edward Elgar. 
Travel Journal (Annual). Japan travel blue book. Tokyo: Travel Journal.

U.S. Census Bureau (2010). The 2010 statistical abstract, the national data book, at http://www.census.gov/compendia/statab/cats/prices.html [accessed 7 September 2010].

U.S. Department of Commerce, Bureau of the Census. Historical statistics of the United States, colonial times to 1970, Part 1. at http://www2.census.gov/prod2/statcomp/documents/CT1970p1-01.pdf [accessed 7 September 2010].

U.S. Department of Commerce, Office of Travel \& Tourism Industries (2010), Historical U.S. travel and tourism statistics and analyses (U.S. outbound). at

http://tinet.ita.doc.gov/outreachpages/outbound_historical_statistics analyses.html

U.S. Department of Commerce, Office of Travel \& Tourism Industries (2008), 2008 United States resident travel abroad.

at http://tinet.ita.doc.gov/outreachpages/download_data_table/2008_US_Travel_Abroad.pdf [accessed 7 September 2010].

U.S. Department of Commerce, Office of Travel \& Tourism Industries (2000), U.S. resident travel to Canada, Mexico, and overseas countries historical visitation outbound, 1989-1999. at http://tinet.ita.doc.gov/view/f-1999-11-001/index.html [accessed 7 September 2010].

Winston, C (1998). "U.S. industry adjustment to economic deregulation." Journal of Economic Perspectives, Vol. 12, September, pp. 89-110. 
Appendix: Table 11.1A

Visitor Arrivals in Hawaii: 1922-2009

\begin{tabular}{|c|c|c|c|}
\hline Year & Number & Year & Number \\
\hline 1922 & 9,676 & 1971 & $1,817,941$ \\
\hline 1923 & 12,021 & 1972 & $2,233,627$ \\
\hline 1924 & 12,468 & 1973 & $2,622,376$ \\
\hline 1925 & 15,193 & 1974 & $2,804,394$ \\
\hline 1926 & 16,762 & 1975 & $2,818,082$ \\
\hline 1927 & 17,451 & 1976 & $3,213,249$ \\
\hline 1928 & 19,980 & 1977 & $3,413,095$ \\
\hline 1929 & 22,190 & 1978 & $3,676,967$ \\
\hline 1930 & 18,651 & 1979 & $3,966,192$ \\
\hline 1931 & 15,780 & 1980 & $3,928,789$ \\
\hline 1932 & 10,370 & 1981 & $3,928,906$ \\
\hline 1933 & 10,111 & 1982 & $4,227,733$ \\
\hline 1934 & 16,161 & 1983 & $4,356,317$ \\
\hline 1935 & 19,933 & 1984 & $4,827,884$ \\
\hline 1936 & 22,199 & 1985 & $4,843,414$ \\
\hline 1937 & 21,987 & 1986 & $5,569,067$ \\
\hline 1938 & 23,043 & 1987 & $5,770,585$ \\
\hline 1939 & 24,390 & 1988 & $6,101,483$ \\
\hline 1940 & 25,373 & 1989 & $6,488,422$ \\
\hline $1942-45$ & Tourism suspended due to WWII & 1990 & $6,723,531$ \\
\hline 1946 & 15,000 & 1991 & $6,518,460$ \\
\hline 1947 & 25,000 & 1992 & $6,473,669$ \\
\hline 1948 & 36,397 & 1993 & $6,070,995$ \\
\hline 1949 & 34,386 & 1994 & $6,364,674$ \\
\hline 1950 & 46,593 & 1995 & $6,546,759$ \\
\hline 1951 & 51,463 & 1996 & $6,723,141$ \\
\hline 1952 & 60,436 & 1997 & $6,761,135$ \\
\hline 1953 & 80,237 & 1998 & $6,595,790$ \\
\hline 1954 & 91,166 & 1999 & $6,741,037$ \\
\hline 1955 & 109,663 & 2000 & $6,948,595$ \\
\hline 1956 & 133,667 & 2001 & $6,303,791$ \\
\hline 1957 & 168,652 & 2002 & $6,389,058$ \\
\hline 1958 & 171,367 & 2003 & $6,380,439$ \\
\hline 1959 & 242,994 & 2004 & $6,912.094$ \\
\hline 1960 & 296,249 & 2005 & $7,416,574$ \\
\hline 1961 & 319,476 & 2006 & $7,528,106$ \\
\hline 1962 & 361,812 & 2007 & $7,496,820$ \\
\hline 1963 & 428,690 & 2008 & $6,713,436$ \\
\hline 1964 & 563,412 & 2009 & $6,514,382$ \\
\hline 1965 & 686,314 & & \\
\hline 1966 & 834,732 & & \\
\hline 1967 & $1,124,012$ & & \\
\hline 1968 & $1,313,706$ & & \\
\hline 1969 & $1,526,074$ & & \\
\hline 1970 & $1,745,904$ & & \\
\hline
\end{tabular}

Sources: Schmitt, 1977, Table 11.7; State of Hawaii Department of Business, Economic Development and Tourism (DBEDT). 
